\section{ECONOMICS}

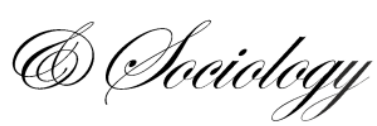

Kolot, A., Kozmenko, S., Herasymenko, O., \& Štreimikienè. D. (2020) Development of a decent work institute as a social quality imperative: Lessons for Ukraine. Economics and Sociology, 13(2), 70-85. doi:10.14254/2071789X.2020/13-2/5

\title{
DEVELOPMENT OF A DECENT WORK INSTITUTE AS A SOCIAL QUALITY IMPERATIVE: LESSONS FOR UKRAINE
}

\author{
Anatoliy Kolot \\ State Higher Education Institution \\ $V$. Hetman KNEU, Ukraine \\ E-mail:kolot@,kneu.edu.ua

\section{Serhiy Kozmenko \\ University of Social Science, Lodz, \\ Poland \\ E-mail: \\ kozmenko.uabs@gmail.com}

\section{Oksana Herasymenko \\ Department of Innovation and \\ Investment Management, Taras \\ Shevchenko National \\ University of Kyiv, Ukraine \\ E-mail: \\ gerasimenko o o@,ukr.net}

\section{Dalia Štreimikienè \\ Lithuanian Institute of Agrarian \\ Economics, Lithuania \\ E-mail: \\ dalia.streimikiene@,knf.vu.lt}

Received: September, 2019

1st Revision: January, 2020

Accepted: May, 2020

DOI: $10.14254 / 2071-$

789X.2020/13-2/5

\author{
JEL Classification:
}

A13, F66, J08
ABSTRACT. The contemporary paradigm for sustainable development assumes single-vector economic and social progress and focuses on human-centrism and social quality. In a human-centered model, people become not only a resource component of sustainable economic growth, but also the main value of society. Human ability to participate in different areas of society, which will enhance well-being and clarify his/her personal potential, is the quintessence of the social quality concept. Under this concept, priority is given to decent work, which outlines an action strategy in implementing social and labor reform to ensure sustainable social and labor development. This study seeks to justify the need to develop a decent work institute in Ukraine as an imperative of social quality. This is based on the concept within which the decent work institute is considered in the context of the Work 4.0 social and labor model, which is inherent in the new Industry 4.0 business structure. Work 4.0 is presented as a theoretical and applied platform of labor and employment. It results from large-scale and multi-vector technical and technological innovations, organizational and business changes that create new opportunities, risks and threats to economically active people in the digital ecosystem. The analysis has revealed the lack of decent work due to threateningly high unemployment, the spread of atypical employment, keeping wage payments to a minimum, destruction of the collective agreement in regulation of social and labor relations, the risks of occupational diseases and work-related incidents. The article substantiates the need to formulate an economic policy which should be based on an effective social and labor policy aimed at overcoming the deficit of decent work, preventing threats to social quality and creating, on this basis, the prerequisites for sustainable socioeconomic development.

Keywords: social and labor sphere, decent work, deficit, crisis of values. 


\section{Introduction}

Socially useful labor plays a paramount role in economic and social development; it is the basis for the well-being of families, the realization of accumulated potential and the selfrealization of laboring people, and, therefore, for the achievement of high standards of social quality. Creating conditions for decent work is one of the priorities in the activities of state institutions, parties and social partnership entities. Successful European integration of Ukraine is not conceivable without creating the conditions for productive, safe, and socially protected work with competitive pay as a reliable source of accumulation and realization of the state's intellectual capital.

Decent work in Ukraine has not yet been the keynote of economic growth and social progress. Therefore, it is necessary to rethink the vectors of social and labor development, which should formulate a qualitatively new socioeconomic policy in the future and use innovation-oriented mechanisms to overcome the decent work deficit. The scientific and applied importance of justifying the decent work institute in ensuring social quality increases.

Profound changes in the field of work and employment, taking place at the stage of the emergence of a new (digital) economy, require new pillars of social and labor development. It is also necessary to integrate the decent work concept into the theory and practice of ensuring sustainable social and labor development, and, in particular, to consider this phenomenon in the context of social quality.

\section{Theoretical background}

The theoretical component of the study is based on the decent work concept, which can be represented as an idea that defines the action strategy in implementing social and labor reform to overcome the decent work deficit and ensure sustainable social and labor development.

Decent work is of paramount importance as it seeks to achieve both economic and social progress. It is vital for all subjects of social and labor relations. Decent work programs provide access to competitive jobs and productive employment. It is extremely important that for an economically active person, decent work is a favorable and safe working environment, adequate remuneration, respect for human rights at work, development of opportunities in the field of formation and growth of human capital, protection of collective and individual interests, and social protection against the risks that are constantly being reproduced. Thus, in decent work conditions, the period of a person's labor activity is filled with natural, most necessary values, such as prosperity, security, freedom, choice, and opportunities. In the areas of social production, where decent work predominates, the wealth of human life, and not just the economy wealth, is at the heart of economic development. For employers, the implementation of the decent work principles is one of the prerequisites for fulfilling the organization's mission, gaining competitive advantages and ensuring sustainable economic development. For the state and society, adoption of decent work principles creates a solid economic foundation for social development (Stukalo et al., 2019; Shkolnyk et al., 2018; Remi, 2018).

The decent work concept includes a set of components that form a theoretical and applied basis for determining progress in the world of work (identifying decent work deficit) and developing mechanisms to ensure decent work at various levels to develop a political platform for implementing decent work principles developed by the International Labor Organization (ILO). This approach allows us to determine prerequisites and factors for decent work through the prism of forms of expression, the causes of decent work deficits and to 
identify the vectors to overcome it. The concept of decent work can be considered as a comprehensive political, economic and social platform that should combine the efforts of public authorities, social partners at all levels of the hierarchical structure of the global economy and national economies, representative bodies of civil society to ensure socioeconomic progress through accessibility and quality of employment. Decent work is also a set of interrelated elements, such as levels, entities, institutions, norms, principles, indicators, characteristics, and mechanisms that will contribute to improving social quality.

The International Labor Organization deserves the credit for initiating and promoting the decent work idea across the globe. In ILO reports, documents, numerous resolutions and other legal and methodological materials, the idea of decent work was introduced to the general public, and the first decent work programs appeared at the national level.

The idea of decent work, which was announced at the 87th Session of the International Labor Conference, is defined as labor with the protected rights of workers, which provides adequate income and social protection. It embodies sufficient work in the sense that everyone has full and free opportunities to earn a living and generate income. Besides, adhering to the principles of decent work means new prospects for economic and social development, new opportunities where employment, income and social protection can be achieved without compromising labor rights and social standards (International Labour Organization, 1999a).

The ILO pilot program provides a broader definition of decent work. It interprets it as work that generates adequate income, leaving time for other aspects of life, providing families with reliability, respecting human rights, providing voice and opening the floodgates for social integration. Decent work is a path that brings economic and social goals together (International Labour Organization, 2000a).

Work is considered decent under conditions of freedom, equality, security and respect for human dignity (International Labour Organization, 1999). Decent work is productive work that respects human rights and guarantees the safety, protection and opportunity to participate in all decisions that may affect the activity of a working person (International Labour Organization, 2000).

Decent work embodies sufficient work, meaning that everyone has full and free access to opportunities to earn and generate income. Adherence to decent work means new perspectives for economic and social development, new opportunities where employment, income and social protection can be achieved without a compromise between workers' rights and social standards (International Labour Organization, 2008). Progress (regress) in the world of work in accordance with the ILO methodology is evaluated by indicators of employment, social protection, observance of workers' rights, and development of the institute for social dialog.

Various definitions of the criteria and indicators of decent work are considered, which form the basis for understanding its essence and content saturation. Anker et al. (2002) describe decent work from the perspective of equal opportunities for men and women to get a decent and productive job in the conditions of freedom, justice, protection and human dignity. The authors also propose potential indicators that can be used in case of relevant changes or innovations in the collection of statistical information (Churilova et al., 2019).

Bescond et al. (2003) point to the choice of indicators such as the evaluation of decent work for socially vulnerable groups (young people, the elderly, children aged 10-14 years, women). Bonnet et al. (2003) propose an integral index, paying the special attention to workers' safety and security. Assessment of access to employment in the context of development has been a feature of the decent work identification (Fields, 2003).

However, the fact that the decent work deficit is a global problem causing low social quality has been neglected. 
The concept of social quality, which interprets social relationships and processes on a regular basis, rests on measuring the quality of social saturation of everyday life. The origins of theoretical understanding of the social quality essence were laid in the concept developed by Beck et al. (2001). Walker (2005) defines social quality as the degree to which people are able to participate in the lives of their communities on terms that contribute to the growth of their well-being and individual capacities. This approach is aimed at people who act as active actors in a developing social environment.

According to Gordon (2007), social quality includes socio-economic security, social inclusion, social cohesion, and empowerment (social authority). Van der Maesen and Walker (2012) extend the architectonics of the social quality components. They add an environmental component and tools for measuring social quality and differentiate all components according to: constitutional factors - processes (human security, public recognition, social responsiveness, and human abilities); predetermined factors - opportunities and unforeseen circumstances (socio-economic security, social cohesion, social inclusion, creating conditions for full participation in society); regulatory factors -orientation (position) (social justice, solidarity, common values, and human dignity).

Given the above, the article hypothesize and proves that decent work is one of the determinants of creating social quality, and the purpose is to justify the need for further development of the decent work institute in Ukraine as an imperative of social quality. This position is consistent with the provisions of the social quality concept, as a mutually exclusive alternative to capitalist modernization of the economy, which is characterized by the loss of the "social component".

\section{Results}

Acknowledging the ILO's contribution to advancing the principles of decent work, it is an exaggeration to say that they contain an inclusive and comprehensive concept of decent work. The concept is inherently an ILO's appeal to the world's political elites and the social partners to work together to reduce the decent work deficit. As for the holistic, scientifically based concept of decent work, its development is a mission of the scientific community, which should comprehensively substantiate the theory of decent work and develop its road map.

Many objective circumstances inherent in the stage of the new economy also served as an impetus for developing the decent work concept. These circumstances can be reduced to four large groups. They relate to the deepening of the processes of globalization, the internationalization of production, the massive relocation of production between countries; the growing ability of economies to meet the individual and societal needs of people in the workplace above all; the new role of working people as a strategic resource, the intensive transfer of competitive advantages and opportunities for sustainable development, which causes changes in the world of work and the socialization of working life; problems created by the digital economy, such as the new social and labor realities.

Forecasts for the future social and labor sphere remain unfulfilled. Instead of vivid estimates for the society's development in the late 20th and at the beginning of the $21 \mathrm{st}$ century, a number of negative trends emerged in the second decade of the new era: increased income inequality, lack of positive dynamics in terms of increasing the share of intellectual labor in total labor costs, widening differences in labor incomes, reduced pace of growth of the human development index, etc. Such consequences negatively influence socio-economic well-being of the state, including labor relations sphere (Bilan et al., 2020). 
Therefore, positive trends in the world of work and social and labor relations should be the strategic benchmark of consolidating competitive positions in the socialized society as the embodiment of the decent work ideology.

The implementation of the decent work principles directly affects overcoming the excessive inequality in the incomes of the economically active population. Statistics and the results of special studies show that rising inequality correlates with the decent work deficit (Table 1).

Table 1. Data on regional disparities (inequality) in household incomes and their linkage to the decent work deficit

\begin{tabular}{cccc}
\hline $\begin{array}{c}\text { Gini } \\
\text { coefficient }\end{array}$ & $\begin{array}{c}\text { Level of } \\
\text { inequality }\end{array}$ & Regional structures & $\begin{array}{c}\text { Level of the decent work } \\
\text { deficit in the regions } \\
\text { concerned }\end{array}$ \\
\hline$<0,3$ & Low & $\begin{array}{c}\text { Central, North, Northeastern Europe, } \\
\text { the Continent. }\end{array}$ & Relatively low \\
\hline $0,3-0,4$ & Medium & $\begin{array}{c}\text { Mainly Southern Europe, Anglo-Saxon } \\
\text { countries, Baltic states, some Asian } \\
\text { countries. }\end{array}$ & Medium \\
\hline $0,4-0,5$ & High & $\begin{array}{c}\text { CIS countries, many countries in Asia, } \\
\text { Latin America and Africa. }\end{array}$ & High \\
\hline$>0,5$ & Very high & $\begin{array}{c}\text { Mainly Latin American and African } \\
\text { countries. }\end{array}$ & Very high \\
\hline
\end{tabular}

Source: Compiled based on the ILO's materials.

The implementation of the decent work principles has also a direct impact on the progressive changes in the society's social stratification and, above all, on the establishment of a powerful middle class. Consistent expansion of the decent work segment is the shortest way to reduce poverty among the working population and to cope with inequalities and discrimination.

Figure 1 shows the distribution of household incomes in OECD countries and in Ukraine, which reflects not only the existence, but also the polarization in incomes. The same results are proved in other researches (Mishchuk et al., 2019; Bilan et al., 2020).

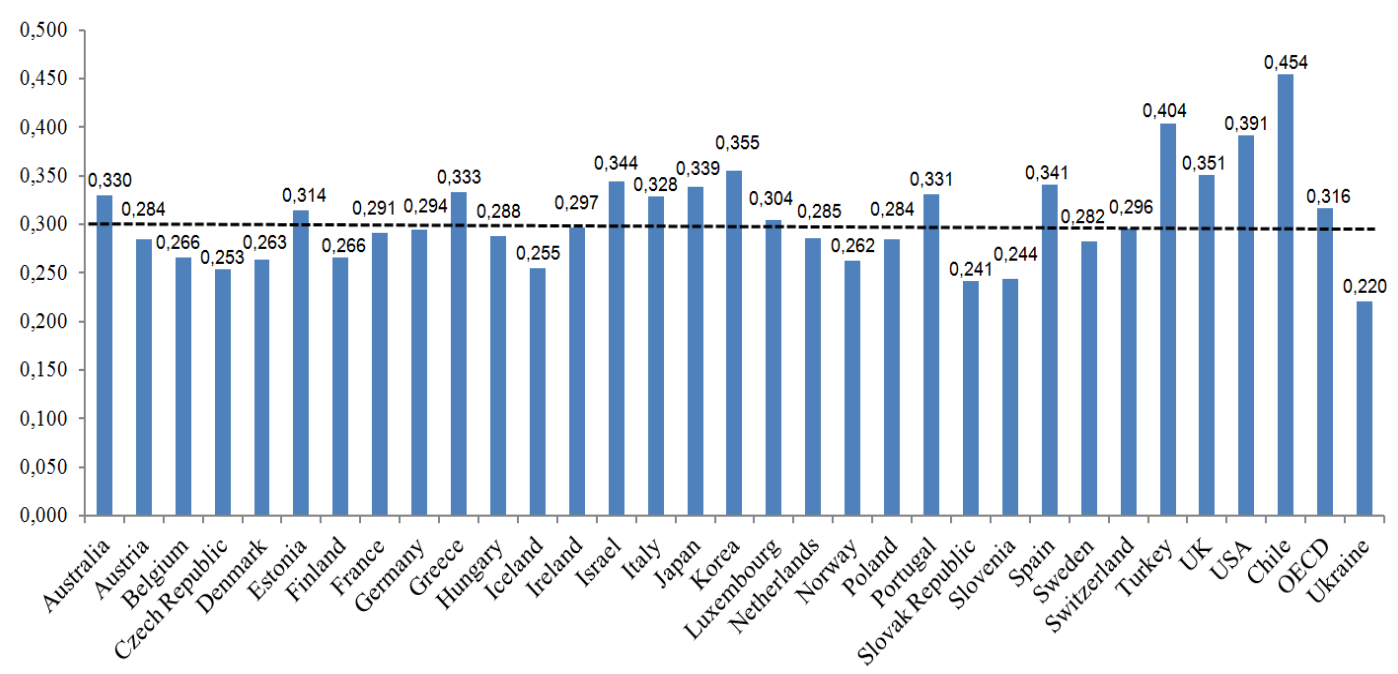

Figure 1. Income distribution (Gini coefficient) in OECD countries and in Ukraine in 2016 
Source: Compiled based on the OECD Income Distribution Database.

URL: https://stats.oecd.org/Index.aspx?DatasetCode=IDD; and a statistical digest

Expenditures and Resources of the Ukrainian Households.

URL: http://www.ukrstat.gov.ua/druk/publicat/Arhiv_u/17/Arch_vrd_zb.htm

All over the world (including Ukraine), the social and labor sphere is facing new challenges. The trends and dominants of its development are so contradictory that it becomes increasingly difficult to understand the depth of these problems.

New social-labor, socio-economic, purely social paradigms, projects, theories, and concepts can and should appear in society, but this does not say no to those principles that adopt and continue to adopt decent working life in the broadest context.

There is a close link between two socially significant human oriented institutes, a Decent Work Institute and a Human Development Institute.

The Decent Work Institute influences human development through the achievement of core values, such as the expanded segment of competitive jobs and productive employment, decent labor income, decent job security, decent job safety, decent rights and opportunities for various actors to be involved in solving social and labor issues. Human development contributes to qualitative change in all components of decent work. Human empowerment also expands opportunities for effective employment. Participation in public life as a component of human development contributes to the development of social dialog. Human development, based on the rights and freedoms proclaimed by international and national acts, promotes the realization of labor rights, strengthens labor protection, and increases the potential for participation in decision-making.

Previous studies (Kolot \& Herasymenko, 2017; Kolot et al., 2017) show that the vast majority of socio-economic and socio-psychological problems faced by economically active people in the Ukrainian labor market are directly or indirectly related to the lack of decent jobs and decent work. The forms of manifestation of the decent work deficit in Ukraine are as follows:

- overt or covert maintenance and permanent growth of unemployment;

- the spread of atypical employment and atypical labor contracts;

- an increased share of jobs that do not provide a socially acceptable labor income;

- poor working conditions and growing social insecurity of workers; and

- increasing asymmetries in the social and labor sphere, which contribute to maintaining and increasing the decent work deficit.

Asymmetries in economic and social development, instability, desocialization of relations in the world of work, reduced social cohesion and increased social isolation are all undesirable trends.

The reasons that destabilize the social and labor sphere in Ukraine are at the same time the reasons that limit the development of the decent work institute, namely:

- low competitiveness of the economy and its large-scale de-industrialization, controversial effects of globalization, its impact on all components of the decent work institute;

- the dominance of neoliberal policy, a component of which is the so-called econocentrism, and the consequence is the establishment of priorities of economic interests over social ones, when the interests of the popular majority in terms of human development are sidelined; 
- formation of a new (digital) economy, which totally changes the traditional elements of the labor market (supply, demand, price of labor services) and its functioning mechanisms;

- increased segmentation of the social and labor sphere in which pre-industrial, industrial and post-industrial control structures and methods are used;

- transformation of the employment institute and multiple changes in the labor market;

- reducing the role of social dialog in optimizing relations between leading social actors;

- the low role of the state in ensuring sustainable development of social and labor sphere;

- limited scope and formal nature of implementation of the Social Responsibility Institute in the field of work and social-labor relations;

- crisis of values of society in general and working life values in particular.

In Ukraine and in most OECD countries (judging by the Gini index), the level of decent work is relatively low. However, optimism about the social and labor future is directly dependent not only on income differentiation, but also on the status and prospects of decent and reliable jobs. Significant changes that are currently taking place in the sphere of employment in Ukraine are an objective response of the economic system and its social and labor components to the dynamic technological, organizational, motivational, and consumer challenges. In Ukraine, as in most countries across the globe, not only the scale, but also the content, structure, types and forms of employment are changing. Labor market is gradually taking on global trends. In Ukraine, the main employment indicators over the past 10 years (see Table 2) show the existence of the decent work deficit in terms of unemployment rates, minimum wage, and social dialog scope, harmful and dangerous working conditions (Kozhemiakina et al., 2018).

Inefficient employment, which generates high unemployment, is the dominant risk in ensuring social quality. 2014-2018 statistics indicate the negative dynamics of the main decent work indicators and the imbalance of key parameters of the labor market as internal factors for reducing social quality in Ukraine. Thus, according to the State Statistics Service of Ukraine's official data, the unemployment rate in Ukraine amounted to $8.8 \%$ in 2018 , exceeding the average unemployment rate in the European Union $(6.8 \%)$ and most European countries. In 2014, the unemployment rate increased significantly in Ukraine, by 2.1 percentage points compared to the previous year. This situation confirms the labor market crisis due to the hostilities in eastern Ukraine. In 2018, the unemployment rate dropped significantly over the past five years and amounted to $8.8 \%$, the 2009 level.

Among the challenges and threats to creating preconditions for decent work, one should emphasize atypical employment that contributes to a decrease in staffing. In 2014, the average number of full-time employees decreased from 8959 thousand to 7662 thousand in 2018 , that is the reduction amounted to $14.5 \%$. In addition to employees who worked under civil law contracts, this was facilitated by the declining dynamics of the total number of employed. Seasonality, as a sign of atypical employment, is one of the major causes for unemployment. Its share among the causes of unemployment in the Ukrainian economy is about $10 \%$. 
RECENT ISSUES IN ECONOMIC DEVELOPMENT

Table 2. Indicators of the decent work deficit in Ukraine for 2014-2018

\begin{tabular}{|c|c|c|c|c|c|}
\hline Indicator name & 2014 & 2015 & 2016 & 2017 & 2018 \\
\hline \multicolumn{6}{|c|}{ 1. Unemployed population aged $15-70$ years } \\
\hline Number, thousand people & 1847,6 & 1654,7 & 1678,2 & 1698,0 & 1578,6 \\
\hline \multicolumn{6}{|l|}{ including by reason of unemployment, $\%$} \\
\hline dismissed for economic reasons & 22,3 & 27,8 & 22,4 & 23,2 & 20,7 \\
\hline dismissed at their own request, as agreed by parties & 31,8 & 28,9 & 33,0 & 34,5 & 38,0 \\
\hline $\begin{array}{l}\text { unemployed after graduation from general and higher } \\
\text { education institutions }\end{array}$ & 16,7 & 16,4 & 15,6 & 12,2 & 9,8 \\
\hline $\begin{array}{l}\text { Share in the labor force (economically active population), } \\
\%\end{array}$ & 9,3 & 9,1 & 9,3 & 9,5 & 8,8 \\
\hline \multicolumn{6}{|c|}{ 2. Off the books } \\
\hline Number, thousands of people & 4540,9 & 4303,3 & 4469,9 & 3695,6 & 3541,3 \\
\hline $\begin{array}{l}\text { Share in the total number of employed population aged } 15- \\
70 \text { years, } \%\end{array}$ & 25,1 & 26,2 & 27,5 & 22,9 & 21,6 \\
\hline \multicolumn{6}{|c|}{ 3. Employees who worked under civil law contracts } \\
\hline Number, thousands of people & 227,1 & 217,4 & 244,8 & 189,9 & 166,7 \\
\hline $\begin{array}{l}\text { Share in the total number of employed population aged } 15- \\
70 \text { years, } \%\end{array}$ & 1,3 & 1,3 & 1,5 & 1,2 & 1,0 \\
\hline \multicolumn{6}{|c|}{ 4. Employees on leave without pay ${ }^{1}$} \\
\hline Number of full-time employees, thousands of people & 90,5 & 62,6 & 163,6 & 37,3 & 18,4 \\
\hline $\begin{array}{l}\text { Share in the total number of employed population aged } 15- \\
70 \text { years, } \%\end{array}$ & 0,5 & 0,4 & 1,0 & 0,2 & 0,1 \\
\hline Share in the average number of full-time employees, $\%$ & 1,0 & 0,8 & 2,1 & 0,5 & 0,2 \\
\hline \multicolumn{6}{|c|}{ 5. Part-time employees ${ }^{2}$} \\
\hline Number of full-time employees, thousands of people & 888,1 & 742,1 & 464,2 & 140,1 & 130,4 \\
\hline $\begin{array}{l}\text { Share in the total number of employed population aged } 15 \text { - } \\
70 \text { years, } \%\end{array}$ & 4,9 & 4,5 & 2,9 & 0,9 & 0,8 \\
\hline Share in the average number of full-time employees, $\%$ & 9,9 & 9,2 & 5,9 & 1,8 & 1,7 \\
\hline \multicolumn{6}{|c|}{ 6. Employed population with a minimum December wage } \\
\hline Number of full-time employees, thousands of people & 394,2 & 217,8 & 220,3 & 506,8 & 436,7 \\
\hline $\begin{array}{l}\text { Share in the total number of employed population aged } 15- \\
70 \text { years, } \%\end{array}$ & 2,2 & 1,3 & 1,4 & 3,1 & 2,7 \\
\hline Share in the average number of full-time employees, $\%$ & 4,4 & 2,7 & 2,8 & 6,6 & 5,7 \\
\hline \multicolumn{6}{|c|}{ 7. Employees not covered by collective agreements } \\
\hline Number of full-time employees, thousands of people & 2156,5 & 1861,5 & 1947,6 & 1941 & 1762,4 \\
\hline $\begin{array}{l}\text { Share in the total number of employed population aged } 15- \\
70 \text { years, } \%\end{array}$ & 11,9 & 11,3 & 12,0 & 12,0 & 10,8 \\
\hline Share in the average number of full-time employees, $\%$ & 24,1 & 23,1 & 24,8 & 25,3 & 23,0 \\
\hline \multicolumn{6}{|c|}{ 8. Employees working in conditions that do not meet sanitary standards } \\
\hline Number of full-time employees, thousands of people & 1075,7 & 898,7 & $\ldots$ & 838,6 & $\ldots$ \\
\hline $\begin{array}{l}\text { Share in the total number of employed population aged } 15- \\
70 \text { years, } \%\end{array}$ & 6,0 & 5,5 & ... & 5,2 & $\ldots$ \\
\hline Share in the average number of full-time employees, $\%$ & 12,0 & 11,1 & $\ldots$ & 10,9 & $\ldots$ \\
\hline \multicolumn{6}{|c|}{ For reference: } \\
\hline $\begin{array}{l}\text { Total number of labor force (economically active } \\
\text { population aged } 15-70 \text { years), thousands of people }\end{array}$ & 19920,9 & 18097,9 & 17955,1 & 17854,4 & 17939,5 \\
\hline $\begin{array}{l}\text { Total number of employed population aged 15-70 years, } \\
\text { thousands of people }\end{array}$ & 18073,3 & 16443,21 & 16276,9 & 16156,4 & 16360,9 \\
\hline $\begin{array}{l}\text { Share of employed population in the labor force } \\
\text { (economically active population), } \%\end{array}$ & 56,6 & 56,7 & 56,3 & 56,1 & 57,1 \\
\hline $\begin{array}{l}\text { Average number of full-time employees, thousands of } \\
\text { people }\end{array}$ & 8959 & 8065 & 7868 & 7679 & 7662 \\
\hline
\end{tabular}

Source: Compiled using data from Economic Activity of the Ukrainian Population and Labor of Ukraine statistical digests (State Statistics Service of Ukraine). URL: http://ukrstat.gov.ua/

\footnotetext{
1 2017-2018 data are given as of the $4^{\text {th }}$ quarter of the corresponding year.

2 2017-2018 data are given as of the $4^{\text {th }}$ quarter of the corresponding year.
} 
In 2014-2018, dismissals at one's own request or as agreed by parties (the peak was in $2018-38.0 \%$ ) and dismissals for economic reasons (the peak was in $2015-27.8 \%$ ) were the main reasons for unemployment. The dismissal at one's own request usually confirms dissatisfaction with the work at an enterprise (in an organization, a company), which is due to the decent work deficit, and the dismissal due to economic reasons is caused by labor surplus, which is a consequence of the reduced competitiveness of the economic entity's products and services, and as a result - by financial and economic downfall. The decrease in Ukrainian enterprises' activities has led to unpaid vacations or part-time employment. In recent years, such forms of atypical employment are characterized by declining trends both in terms of the number of employees and their share in the total number of employed population and in the average number of full-time employees. Unpaid leave and part-time employment are trajectories of a significant drop in incomes and escalation of poverty.

Keeping wages at a minimum level, which causes a decrease in living standards and significantly impairs social quality, makes it difficult to implement the principles of decent work. And labor remuneration is one of the more important issues (Tsymbaliuk et al., 2019).

In Ukraine, in recent years, the value of the collective agreement based regulation of social and labor relations at the national, regional, sectoral and industrial levels has sharply decreased. Even at the height of its development (in the early 2000s), it was far from the best European practice. Legally speaking, Ukraine has all the attributes of social partnership at different levels (from national to business). However, various forms of social dialog and, in particular, the conclusion of deals and collective agreements are too inefficient. Agreements in force at the national and sectoral levels do not ensure favorable relations in the field of labor and employment. The proportion of employees not covered by collective agreements is about a quarter of the average number of full-time employees. The protective and regulatory function of collective agreements is also being rapidly nullified.

Attention should also be paid to the risks of occupational diseases and occupational injuries, which cannot be avoided due to work in conditions that do not meet sanitary and hygienic standards. Despite the observable decrease in the number of people working in such conditions, the mere fact of having jobs that pose a threat to health is a serious challenge to decent work and social quality.

The magnitude and depth of social and labor problems, asymmetries in economic and social development in Ukraine as signs of the decent work deficit are endangering social quality. Through the prism of employment, income, working conditions, social protection and other system-forming components of social and labor development, both new opportunities for economically active people under the new (digital) economy and new challenges, risks and threats are clearly observed.

Given this, an updated concept of decent work implies considering this institute in the context of the Work 4.0 model. It is also viewed as a theoretical and applied platform of work and employment, which should operate according to the decent work principles in the new (digital) economy. The growing impact of digital skills and ICT development on economic growth including employment sphere is an obvious reality that shifts the socio-labor relations rapidly (Bilan et al., 2019).

Work 4.0, on the one hand, and Industry 4.0, on the other, are two sides of the same coin - social and labor and technical and technological ones. Industry 4.0 is a new economic pattern that emerged from the Fourth Industrial Revolution, characterized by the development of the digital ecosystem. The following innovation technologies have triggered changes: IoT (Internet of Things), Data Driven Decision (Big data-based analytics and decision-making), Connected Machines (direct machine interaction), Artificial Intelligence, OneDrive (cloud storage service), biotechnologies, and 3D printing. In a narrow sense, Industry 4.0 is a 
consolidated platform that combines key actors of a given country or region and incorporates not only new technologies, but also new production models and a new business culture (Türksel et al., n.d.; Rüßmann et al., 2015; Wanjiru et al., 2017; Schwab, 2016, 2016a; Kagermann \& Wahlster, 2011; Kergroach, 2017; Federal Ministry of Labour and Social Affairs of Germany, 2017).

The Work 4.0 model is not a product of linear, one-vector technical and technological transformations. It is the result of a symbiosis of large-scale, multi-vector, and ambiguous transformational transformations that change business models and ways of doing business.

More generally, the development and functioning of Industry 4.0 in the field of labor and employment (Model 4.0) will lead to:

- potentially significant, favorable technical and technological preconditions for increasing labor productivity;

- a sharp decrease in the complexity of social production and labor demand contraction;

- diversified work statuses, dominance of atypical employment;

- increased workforce differentiation by the level of vocational training and competence;

- increased requirements for training, personal qualities and abilities of employed in the new economy;

- critical changes in the nature and organization of work;

- new preconditions and opportunities for communication, dialog and cooperation;

- strengthened control over the labor process, including remote work;

- increased work intensity in most types of work;

- transformation of many types of work, namely from complex and super-complex to simplified and simple ones;

- shortening the "life cycle" of the use of acquired knowledge; their actualization and construction;

- new competences (abilities, skills) that become critical for an economically active person.

Work 4.0 is shaped not only by the technical and technological innovations of the Fourth Industrial Revolution (Industry 4.0). New demographic realities, the modern format of digital economy globalization (the so-called "second" and "third" divisions), and the global political and economic platform (neoliberalism, economocentrism, the primacy of economic over social) are important factors in the transformation of the social and labor sphere. Meanwhile, current realities testify to the emergence of the "market - state - business" triad, which is new in terms of content and configuration. This triad shows the new role of market mechanisms, state intervention, and participation of business organizations in regulating social and labor development and demonstrates the need to increase their contribution to ensuring economical upturn and positive social dynamics (Kolot \& Herasymenko, 2017).

\section{Discussion}

In the context of these provisions, it is unacceptable to argue that commodification is the main feature of current capitalism, that is, the transformation of everything, including the individual, into a commodity, and that the economy is increasingly alienated from society, and that tomorrow each of us can be granted precarium (Standing, 2011). Besides, the idea that the world is moving to the left in the direction of man, that today intensive dematerialization of the economic space is already underway and a new socio-centric human- 
oriented economy is being formed, is also mistaken (Galchinsky, 2016). Giddens' estimates of victory over material wealth as the major event of the 20th century are also exaggerated (Giddens, 2014).

The crisis in the values of working life is aggravated in Ukrainian society. It is necessary to constantly monitor their dynamics, identify risks of social and labor asymmetries and take measures to prevent negative trends in social and labor relations.

It is proposed to re-write the modern values of working life, assess the true role of social, moral, mental, and non-economic aspects in our lives, and move on to a search for a new paradigm of life issues.

Influenced by many factors, both internal and external, the world of work and social and labor relations change controversially, and such changes will continue to intensify. This determines the need for a comprehensive, objective, and impartial analysis of the social and labor sphere transformation, identifying characteristic trends, tendencies, and dominants of social and labor development.

The research urges us to update a decent work theory. This theory should make away with fragmentation, common slogans and judgments and become a theoretical basis for building human-oriented relations in the world of work. The new concept of decent work should, first, be an extensive system of scientific perspectives on the development of the world of work based on the decent work principles. It also should become the basis for developing institutional support for decent work and acquire the status of a platform on which the state contractual and managerial levers of influence on the main components of decent work should be formed.

The idea of decent work does not dominate among those in a position to form and implement social and labor policy. In view of this, one should insist on the particular importance of the worldview (and also educational) function of the decent work concept. The essence of the worldview function of the decent work concept is that the basic provisions and general philosophy should contribute to modern economic thinking, a renewed understanding of the interconnectedness and interdependence of social work and economic progress, the formation of socially responsible activities in the social and labor sphere.

The modern philosophy of decent work and the socio-economic mechanisms of deficit management based on it are proposed to be considered as a democratic requirement of society for governmental structures, social partners of all levels to create decent jobs, expand access to them and create proper conditions (legal, organizational, economic, institutional, psychophysiological, etc.) for productive employment. Such a demand is aimed at overcoming the deficit of decent work, further developing the social and labor sphere, and improving social quality.

Any actions of state institutions are doomed to failure without new approaches to formulating social and labor policies, without realizing the need for a new structure and hierarchy of development factors, without understanding that today a highly professional economic policy aimed at building a new economy, the sources of development of which are innovative labor and intellectual capital, is the most optimal socio-labor policy. These actions are also impossible without a new perception of the person's role, her/his motives and interests. At best, society will experience economic growth without social development, and at worst, economic and social degradation. 


\section{Conclusion}

The social and labor sphere in Ukraine is transforming faster and faster, but the decent work segment does not show steady positive dynamics, does not have a clear road map for development, and does not have the potential to improve social quality.

Among the main reasons for this situation are the insufficient study of the problem, the lack of fundamental knowledge about the prospects of a decent work institute in the context of a new (digital) economy, an integral part of which is the Industry 4.0 business structure and the Work 4.0 social and labor model (platform).

The concept of developing a decent work institute in the context of social quality presented in the article is based on theoretical and applied developments, implemented with the support of the International Labour Organization and other international institutions, and takes into account the latest trends in the transformation of social and labor sphere caused by the advent of the digital ecosystem. Deepening globalization processes, internationalization of production, mass transfer of production between countries; the growing ability of the economy to meet the individual and societal needs of members of society, especially in the field of direct employment; the new role of a working person as a strategic resource and the bearer of competitive advantages and opportunities for sustainable development have given rise to a new social and labor reality that puts forward new requirements for decent work parameters.

National decent work programs developed by the International Labour Organization for ILO member countries have embodied the ideology of decent work in the global world, and the priorities of these programs have received strong support in their implementation.

The authors of the article believe that legal, institutional, economic, and social reforms aimed at implementing the basic principles of decent work should, first of all, help to eliminate the decent work deficit and, as a result, improve social quality.

The rationale for the development of a decent work institute presented in the article serves as a scientific and applied scenario for finding the prerequisites and factors of decent work in the coordinates of the new economy. Identified trends in the spread of atypical employment and atypical employment contracts; increased share of jobs that do not provide a socially acceptable level of labor income; unsatisfactory working conditions and growing social insecurity of employees in various forms of expression; the desocialization of relations in the world of work, and the reduction of social cohesion by destroying the collective agreement based regulation of social and labor relations outline the main vectors for overcoming the decent work deficit.

Based on the lessons Ukraine has learned from widening and deepening decent work deficits as a blood clot on the path to ensuring social quality, socially responsible representatives from academia should demonstrate their involvement in the development of mechanisms and tools for ensuring decent work at the level of the national economy of Ukraine and individual entities, and the political and business environment should develop a roadmap and ensure measures implementation in practice.

Positive trends in the field of labor and social-labor relations that have emerged in the process of overcoming the decent work deficit should become a strategic guideline for ensuring competitive positions in the coordinates of a socialized society, lay new pillars to ensure the stability of social and labor development, and achieve higher social quality on this basis.

According to the authors, the vectors of social and labor development, which in the future should form a qualitatively new socio-economic policy in Ukraine, should include: 
- the introduction of an innovative employment model based on an increase in the size of the tertiary sector and the innovation sphere, increasing the level of competitiveness of jobs, and the use of highly qualified workforce;

- improving labor income policy based on modernization and increasing the efficiency of social standards, updating and filling the existing mechanisms for regulating income (primarily the personal income taxation system) with new instruments, improving the collective agreement based wage regulation, and distributing individualized remuneration;

- reforming the social protection system by reformatting the tasks of the state, developing the institutional environment, and implementing a number of measures at the macro level;

- the improvement of regulatory and applied support, organizational and informative measures and social responsibility at all levels; collective agreement based regulation of safety and health at work and professional health of personnel on the basis of a preventive approach;

- the implementation by government bodies, trade unions and employers' organizations of specific practical means of a broad approach to social dialog, which contributes to joint decision-making and agreements that will underlie the state's socio-economic policy on the implementation of decent work elements;

- building a new model of social state based on the formation of socio-economic preconditions for decent work, and not just social support for economically active people; developing a corporate social responsibility policy to build a brand and image, competitiveness, increase capitalization, strengthen sustainability, and improve stakeholder engagement;

- modernization of applied aspects of collective agreement based regulation of social and labor relations in terms of filling collective agreements with qualitatively new content at the national, sectoral and regional levels.

This study should help rethink the dominants of the development of the world of work in general and decent work, in particular, in the context of Work 4.0, a new social and labor reality that should form a new economic thinking and a new economic culture in the future, use innovative oriented mechanisms to overcome the decent work deficit and ensure a high level of social quality.

\section{References}

Abbott, P., Wallace, C., \& Sapsford, R. (2016). The Decent Society. Planning for Social Quality. London: Routledge.

Anker, R., Chernyshev, I., Egger, P., Mehran, F., \& Ritter, J. (2002). Measuring Decent Work with Statistical Indicators (Working Paper, 2). Geneva: International Labour Office.

Bilan, Y., Mishchuk, H., Samoliuk, N., \& Grishnova, O. (2019). ICT and Economic Growth: Links and Possibilities of Engaging. Intellectual Economics, 13(1). DOI: https://doi.org/10.13165/IE-19-13-1-07

Bilan, Y., Mishchuk, H., Samoliuk, N., \& Yurchyk, H. (2020). Impact of Income Distribution on Social and Economic Well-Being of the State. Sustainability, 12(1), 429; doi:10.3390/su12010429

Beck, W., van der Maesen, L., Walker, A., \& Thomése, F. (2001). Social Quality: A Vision for Europe. The Hague: Kluwer Law International. 
Bescond, D., Chataignier, A., \& Mehran, F. (2003). Seven indicators to measure decent work: An international comparison. International Labour Review, 142(2), 179-212. https://doi.org/10.1111/j.1564-913X.2003.tb00258.x

Bonnet, F., Figueiredo, J., \& Standing, G. (2003). A family of decent work indexes. International Labor Review, 142(2), 213-238. https://doi.org/10.1111/j.1564913X.2003.tb00259.x

Federal Ministry of Labour and Social Affairs of Germany. (2017). White Paper on Work 4.0.

Fields, G. (2003). Decent work and development policies. International Labour Review, 142(2), 239-262. https://doi.org/10.1111/j.1564-913x.2003.tb00260.x

Gachie, W., \& Govender, D. W. (2017). The evaluation of human computer interface design of learning management systems: problems and perspectives. Problems and Perspectives in Management, 15(3), 394-410. doi:10.21511/ppm.15(3-2).2017.08

Galchinsky, A. (2016). The world develops to the left - towards the person. The Week Mirror, 40. (In Ukrainian).

Ghai, D. (2003). Decent work: Concept and indicators. International Labor Review, 142(2), 113-145. https://doi.org/10.1111/j.1564-913x.2003.tb00256.x

Churilova, E., Salin, V., Shpakovskaia, E., \& Sitnikova, O. (2019). Influence of world social and economic indicators' interlinkage on the development of human potential. Journal of International Studies, 12(4), 79-99. doi:10.14254/2071-8330.2019/12-4/6

Giddens, A. (2014). Turbulent and Mighty Continent: What Future for Europe? Cambridge: Polity.

Gordon, D. (2007). Measuring Social Quality in Asia and Europe: with Particular Reference to Socio-economic Security. The Second Social Quality Conference in Asia «Social Quality and Sustainable Welfare Societies: Towards a new partnership between Asian Universities and Universities of the European Union». Offprint 1.

Human Development Report 2014 (2014). Sustaining Human Progress: Reducing Vulnerabilities and Building Resilience. New York: UNDP.

International Labour Organization. (1999). Decent work for All in a Global Economy. Retrieved from

http://www.ilo.org/public/english/bureau/dgo/speeches/somavia/1999/seattle.htm

International Labour Organization. (1999a). Decent work. Report of the Director-General. 87th Session of the International Labour Conference. Geneva: International Labour Office.

International Labour Organization. (2000). Decent Work in the Information Economy. Report of the Director-General. Geneva.

International Labour Organization. (2000a). Decent work pilot program. Retrieved from http://www.ilo.org/public/english/bureau/dwpp/

International Labour Organization. (2001, June). Reducing the Decent Work Deficit - a Global Challenge, Report of the Director-General. 89th Session International Labour Office. Geneva.

International Labour Organization. (2002, June). Decent Work and Informal Economy. Report VI submitted to the 90th Session of International Labour Conference. Geneva.

International Labour Organization. (2008). Decent Work: Some Strategic Challenges Ahead. Report of the Director-General. 97th Session of the International Labour Conference. Geneva: International Labour Office.

International Labour Organization. (n.d.). Measuring Decent Work. Decent Work Country Profiles. Retrieved from http://www.ilo.org/integration/themes/mdw/lang-en/index.htm) 
Kagermann, H., Lukas, W.-D., Wahlster, W. (2011, April 1). Industrie 4.0: Mit dem Internet der Dinge auf dem Weg zur 4. industriellen Revolution. Retrieved from http://www.wolfgang-wahlster.de/wordpress/wp-

content/uploads/Industrie_4_0_Mit_dem_Internet_der_Dinge_auf_dem_Weg_zur_viert en_industriellen_Revolution_2.pdf

Kergroach, S. (2017) Industry 4.0: New Challenges and Opportunities for the Labour Market. Foresight and STI Governance, 11(4), 6-8.

Kolot, A., \& Herasymenko, O. (2017). A deficit of decent work as a current trend in the development of social and labor sphere in Ukraine. Knowledge and Performance Management, 1, 5-18.

Kolot, A., \& Herasymenko, O. (2017a). Market, state and business in coordinates of the new economy. Problems and Perspectives in Management, 15(3), 76-97.

Kolot, A. M., Daniuk, V. M., Herasymenko, O. O., et al. (2017). Decent Work: Imperatives, Ukrainian Realities, Implementation Mechanisms. Kyiv: KNEU. (In Ukrainian).

Kozhemiakina, S., Cherkasov, A., Reznik, N., Yazlyuk, B., Zhuravka, O., \& Mazurov, S. (2018). New workplace forecasting in the industrial sector of the Ukrainian economy. Problems and Perspectives in Management, 16(4), 384-394. doi: $10.21511 / \mathrm{ppm} .16(4) .2018 .32$

Lin, K., \& Herrmann, P. (2015). Social Quality Theory. A New Perspective on Social Development. New York: Berghahn Books.

Mishchuk, H., Samoliuk, N., \& Bilan, Y. (2019). Measuring social justice in the light of effectiveness of public distributive policy. Administration \& Public Management Review, (32). 63-76. DOI: 10.24818/amp/2019.32-05.

OECD. (2011). Eastern Partner Countries. Progress in the Implementation of the Small Business Act. Paris.

Reni, S. (2018). Dimensionality of intra-organizational conflict and the challenges for human resource management in small and medium scale enterprises in Nigeria. Journal of Competitiveness, 10(1), 125-143, DOI: 10.7441/joc.2018.01.08

Rüßmann, M., Lorenz, M., Gerbert, P., Waldner, M., Justus, J., Engel, P., \& Harnisch, M. (2015). Industry 4.0: The Future of Productivity and Growth in Manufacturing $\begin{array}{llll}\text { Industries. Boston Consulting } & \text { Group, }\end{array}$ http://www.inovasyon.org/pdf/bcg.perspectives_Industry.4.0_2015.pdf

Schwab, K. (2016). The Fourth Industrial Revolution (172 p.). Cologny/Geneva, Switzerland: World Economic Forum.

Schwab, K. (2016, January 14). The Fourth Industrial Revolution: What it Means, How to Respond. Retrieved from https://www.weforum.org/agenda/2016/01/the-fourthindustrial-revolution-what-it-means-and-how-to-respond/

Shkolnyk, I., Mershchii, B., \& Melnyk, T. (2018). Assessment of quality of financial support for local social development in Ukraine. Public and Municipal Finance, 7, 19-28. doi:10.21511/pmf.07(4).2018.03)

Standing, G. (2011). The Precariat: The New Dangerous Class. London: Bloomsbury Academic.

Stukalo, N., Simakhova, A., \& Shmarlouskaya, H. (2019). Special features of formation of the source base for economic socialization. Problems and Perspectives in Management, 17(3), 271-279. doi:10.21511/ppm.17(3).2019.22

Tsymbaliuk, S., Wyrwa, D., \& Shkoda, T. (2019). Remuneration policy in terms of decent work at a regional level. Problems and Perspectives in Management, 17(4), 80-92. doi:10.21511/ppm.17(4).2019.07 
Türksel Kaya Bensghir, Ufuk Türen, \& Yücel Y1lmaz. (n.d.). How a Workforce in Industry 4.0 Era? LABOR 4.0. DOI: 10.3726/b15120. In Industry 4.0 from the MIS Perspective (Chapter 5, pp. 67-80). Peter Lang GmbH.

van der Maesen, L. J. G., \& Walker, A. (2012). Social Quality: From Theory to Indicators. New York: Palgrave MacMillan.

Walker, A. (2005). Which Way for the European Social Model: Minimum Standards on Social Quality? In The Changing Face of Welfare (pp. 33-53). Bristol: Policy Press. 